\title{
PENINGKATAN KUALITAS PEMBELAJARAN FISIKA DI SMAN 2 MATARAM MELALUI PENERAPAN PENDEKATAN KETERAMPILAN PROSES
}

\author{
Syahrial Ayub ${ }^{1 *}$, I Wayan Gunada ${ }^{1}$, Gusti Afifah ${ }^{2}$ \\ ${ }^{1)}$ Program Studi Pendidikan Fisika Universitas Mataram \\ ${ }^{2)}$ SMA Negeri 2 Mataram \\ *Email: syahrial_ayub@unram.ac.id
}

DOI: http://dx.doi.org/10.29303/jpft.v5i1.1135

\begin{abstract}
This collaborative action research which was aimed to improve the quality of physics teaching through the implementation curriculum of 2004 in teaching scenario which oriented for process skill. This action research was conducted to the second year students of The State Senior High School 2 Mataram, by involving two teachers for giving the treatmen. The data needed such as observation result of teaching inthe class and the student response were collected by observation format of teaching in the class and questionnare. By using quantitative and qualitative analysis, it was found that 1) the implementation of process skill teaching can quality improvement of physic teaching in The State Senior High School 2 Mataram, 2) student's response for implementation of process skill teaching is good, 3) the student's opinion toward implementation of process skill teaching is quantitatively positive. Based on this result, it is recommended that physic teacher implement process skill teaching of teaching continuosly in order to improve student's achievement.
\end{abstract}

Keywords: Process Skill Teaching, Teaching Quality.

\section{PENDAHULUAN}

Berbagai usaha, telah dilakukan pemerintah untuk meningkatkan mutu pendidikan dan pengajaran MIPA di SMA. Namun mutu pendidikan MIPA khususnya fisika masih merupakan isu yang hangat dibicarakan diberbagai forum ilmiah saja (Huda, 2013). Akibatnya hasil belajar siswa rendah. Masalah rendahnya hasil belajar fisika siswa juga terjadi di SMA Negeri 2 Mataram. Kasus daya serap rendahnya ketuntasan belajar banyak terjadi di kelas non unggulan, yang rata-rata di bawah 50\%. Data ini menunjukkan bahwa kualitas pembelajaran fisika di SMA Negeri 2 Mataram perlu dibenahi.

Dari hasil survei dan observasi, teridentifikasi beberapa permasalahan, yaitu: Pertama, pembelajaran fisika di SMA 2 Mataram masih didasarkan atas asumsi bahwa kepala siswa dipandang sebagai kotak hitam (gelap tentang konsep konsep fisika) yang siap untuk diisi. Konsep-konsep fisika dapat ditransfer dari kepala guru ke kepala siswa. Asumsi ini menyebabkan guru terfokus untuk memberi pengetahuan sebanyak-banyaknya sesuai dengan target kurikulum.

Guru akan merasa mengajar dengan baik bila daya capai kurikulum mencapai $100 \%$, tetapi ternyata guru sering kecewa karena daya serap dan ketuntasan belajar siswa masih rendah dibawah 50\%. Kedua, Pola Pembelajaran fisika di SMA Negeri 2 Mataram berlangsung secara konvensional, guru menganggap siswa seperti botol kosong yang siap untuk diisi sehingga pembelajaran berlangsung satu arah saja, yaitu guru memberi dan siswa menerima. Tampaknya, pembelajaran semacam ini cenderung hanya menghabiskan materi kurikulum daripada menanamkan konsep yang benar pada siswa. Ketiga, selama ini guru fisika di SMA 2 Mataram jarang menggali dan memberikan perhatian pada konsepsi awal siswa terhadap suatu konsep fisika. Hasil penelitian terdahulu (Santyasa, 1997) menunjukkan bahwa pengabaian terhadap gagasangagasan awal siswa telah menimbulkan kegagalan pada pembelajaran fisika. Keempat, kegagalan siswa dalam memecahkan persoalan-persoalan fisika 
diakibatkan oleh siswa tidak dapat melihat adanya keterkaitan antar konsep yang sudah dipelajari dengan konsep yang sedang dipelajari. Hal ini menunjukkan bahwa proses pembelajaran fisika yang dialami belum bermakna. Pembelajaran bermakna akan terjadi bila siswa melihat kaitan diantara konsep-konsep yang dipelajari (Dahar, 1989).

Berdasarkan identifikasi permasalahan tersebut, tampaknya proses pembelajaran fisika di SMA Negeri 2 Mataram perlu dioptimalisasikan. Proses optimalisasi diupayakan dengan mengimplementasikan pendekatan keterampilan proses dalam kegiatan belajar mengajar di kelas.

Berdasarkan hasil survei dan observasi yang dilakukan di SMA Negeri 2 Mataram, secara operasional, permasalahan yang dihadapi pada penelitian ini dapat dirumuskan sebagai berikut: Bagaimanakah meningkatkan kualitas pembelajaran fisika di SMA Megeri 2 Mataram melalui penerapan pendekatan keterampilan proses?

Tujuan dari penelitian ini adalah meningkatkan kualitas pembelajaran fisika di SMA Negeri 2 Mataram dengan mengimplementasikan keterampilan proses dalam pembelajaran di kelas sehingga dapat mengubah iklim pembelajaran fisika di SMA Negeri 2 dari konvensional ke pembelajaran yang creative thinking, joyful learning dan life skill.

Penelitian ini bertolak dari pandangan konstruktivisme yang menyatakan bahwa pengetahuan dibangun dalam pikiran siswa sehingga implikasinya, pengetahuan itu tidak dapat dipindahkan secara utuh dari pikiran pengajar ke pikiran siswa. Siswa sendirilah yang harus aktif secara mental mengkonstruksi pengetahuannya (Klinger,1997).

Pengonstruksian pengetahuan itu terjadi melalui proses asimilasi dan akomodasi (Irawan, 1997). Keterampilan proses merupakan keseluruhan keterampilan ilmiah yang terarah baik kognitif maupun psikomotor yang dapat digunakan untuk menemukan suatu konsep atau prinsip atau teori (Tuada et al. 2017).

Pembelajaran dengan pendekatan keterampilan proses merupakan pendekatan pembelajaran yang bertolak dari filosofi belajar konstruktivisme yang intinya bahwa siswa mengkonstruksi pengetahuannya dalam lingkungan belajarkonstruktivis (Ibrahim, 2000). Menurut Nur (1988) ada beberapa keterampilan dalam pendekatan keterampilan proses yaitu. keterampilan melakukan pengamatan (Observasi), kemudian dilanjutkan dengan keterampilan melaksanakan percobaan (eksperimen). Keterampilan melaksanakan percobaan terdiri dari merumuskan masalah, mengidentifikasi variabel, mengajaan hipotesis, mendefenisikan variabel secara operasional, merencanakan percobaan, melaksanakan percobaan, mengandisis data, dan menyimpulkan hasil percobaan. Menurut (Suwandari et al. 2018) keterampilan proses terdiri dari beberapa keterampilan yang harus dipahami dan dimengerti, yaitu keterampilan mengamati, keterampilan mengklasifikasi, keterampilan menafsirkan pengamatan, keterampilan meramalkan, keterampilan merencanakan dan melaksanakan percobaan, keterampilan menerapkan konsep dan berkomunikasi.

Implementasi pembelajaran dengan pendekatan keterampilan proses dapat membangkitkan motivasi siswa dan rasa ingin tahu siswa tentang dunia fisik, beberapa konsep yang dirasakan sulit bagi siswa menjadi lebih mudah dipahami karena pembelajaran berfokus pada siswa. Salah satu upaya yang dapat dilakukan untuk mengembangkan keterampilan proses siswa yaitu dengan menerapkan Lembar Kerja Siswa (LKS) berupa Lembar Kerja Eksperimen (LKE) (Hikmawati et al. 2019). LKS dan LKE akan memberikan pedoman 
pada siswa dalam belajar menemukan sendiri konsep yang diajarkan.

\section{METODE PENELITIAN}

Penelitian yang dilaksanakan adalah penelitian tindakan kelas. pada tahap awal peneliti menjelaskan dan mempraktekkan cara mengajar dengan pendekatan keterampilan proses baik secara peer teaching maupun real teaching (Ramdhani, 2005). Setelah itu guru langsung mengimplementasikannya dalam pembelajaran di kelas. Implementasi ini juga dituangkan dalam skenario pembelajarannya. Diharapkan dari kemitraan ini, guru maupun peneliti dapat mengambil manfaatnya semoga kualitas pengajaran di sekolah dapat meningkat yang nantinya akan bermuara pada prestasi belajar siswa.

Faktor guru yang diteliti berkaitan dengan kemampuan mengajar denganmenggunakan pendekatan keterampilan proses sebagai implementasi dari kurikulum 2004. Faktor ini akan tercermin dari skenario pembelajaran yang dibuat oleh guru dan tim peneliti. Faktor siswa hanya digunakan untuk mengetahui respon siswa terhadap pendekatan keterampilan proses yang diterapkan guru dalam pembelajaran di kelas.

Penelitian ini di SMA Negeri. 2 Mataram. Subjek penelitian adalah seluruh siswa kelas XI.SMA Negeri 2 Mataram. Objek penelitian adalah peningkatan kualitas pembelajaran fisika dengan menerapkan kurikulum melalui skenario pembelajaran yang berorientasi pada keterampilan proses. Penelitian ini menggunakan rancangan penelitian tindakan kelas yang terdiri alas (4) empat siklus besar. Setiap siklus dilakukan dalam 8 kali pertemuan dimana setiap pertemuan dilakukan selama 2 jam pelajaran. Rincian kegiatan yang dilaksanakan pada setiap siklus adalah:
1) Tahap Perencanaan

Kegiatan yang dilakukan pada tahap ini adalah

a. mengkomunikasikan hasil studi awal tentang profil pembelajaran fisika,

b. mensosialisasikan skenario pembelajaran yang mengimplementasikan kurikulum 2004 kepada guru dan kepala sekolah,

c. membuat skenario pembelajaran dengan pendekatan keterampilan proses yang mencerminkan implementasi kurikulum 2004 pada pembelajaran fisika di SMA,

d. menyusun instrumen penelitian menyepakati indikator-indikator keberhasilan tindakan bersama guru dan peneliti.

2) Tahap Tindakan

Pada tahap tindakan, yang dilaksanakan adalah:

(a) mengumpulkan data pengetahuan awal dan mengidentifikasi kesulitan kesulitan yang dihadapi guru dalam pembelajaran fisika di kelas.

(b) melaksanakan tahapan-tahapan pembelajaran

(c) mengklarifikasi kesulitan-kesulitan guru dalam pembelajaran fisika di kelas dan pengembangan konsep siswa dengan pendekatan keterampilan proses

3) Tahap Observasi/Evaluasi

Pada tahap ini, dilakukan :

a. observasi proses dan penganih tindakan serta hambatanhambatannya dengan menggunakan pedoman observasi;

b. mengevaluasi pencapaian hasil belajar siswa dengan tes hasil belajar

4) Tahap Refleksi

Refleksi dilakukan setiap selesai tindakan bersama-sama tun peneliti untuk mengkaji atau menganalisis temuantemuan dalam tindakan yang telah dilakukan. 
Hambatan dan kelemahan pelaksanaan tindakan perlu dicarikan altematif pemecahannya sebagai masukan pada perencanaan tindakan berikutnya.

\section{HASIL DAN PEMBAHASAN}

Penelitian tindakan kelas ini dilakukan untuk meningkatkan kualitas pengajaran guru fisika di SMA Negeri 2 Mataram dengan menerapkan strategi pembelajaran dengan pendekatan keterampilan proses. Pada penelitian ini telah dihasilkan: a) berbagai skenario pembelajaran dengan pendekatan keterampilan proses, b) lembar kerja siswa dengan pendekatan keterampilan proses dan lembar observasi pembelajaran fisika di kelas yang dapat digunakan oleh kepala sekolah atau pengawas dalam melakukan monitoring di kelas.

Penelitian ini berlangsung dalam empat siklus dengan pembelajaran pendekatan keterampilan proses. Data yang didapatkan dari hasil observasi dan evaluasi pada setup siklus selanjutnya dianalisis dengan metode yang telah ditetapkan sebelumnya. Adapun hasil penelitian dan pembahasan dipaparkan sebagai berikut:

\section{Siklus I}

Pada siklus 1, untuk pertama kalinya siswa diberikan pembelajaran pendekatan keterampilan proses dengan pokok bahasan gaya gesekan. Siklus ini dilaksanakan dalam 8 kali pertemuan yang masing masing pertemuan dilaksanakan selama 2 jam pelajaran. Hasil observasi yang dilakukan pada siklus 1 ini diperoleh:

a) kesiapan guru dalam memberikan pembelajaran dengan pendekatan keterampilan proses masih kurang. Hal ini terlihat kurang konsistennya guru untuk menerapkan metode ini, mendominasi kegiatan pembelajaran. Permasalahan pembelajaran masih diberikan oleh guru, kegiatan (melakukan percobaan, mengamati, menganalisis) untuk memecahkan masalah tersebut juga masih banyak di dominasi oleh guru, dan akhirya guru juga yang menyimpulkan atau menemukan konsep yang ingin diajarkan pada pertemuan itu. Hal ini, terjadi diduga akibat kebiasaan mengajar yang selama ini, dilakukan memang berpusat kepada guru sehingga sudah melekat dan sulit untuk diubah. Hal ini juga tercermin dari komentar guru saat pembelajaran dilakukan oleh ketua tim peneliti yang mengatakan bahwa kalau pembelajaran seperti ini akan menyita waktu yang lama dan sulit bagi anak untuk memprosesnya.

b) kesiapan siswa dalam mengikuti pembelajaran masih kurang, hal ini terlihat dengan banyak-nya siswa yang tidak membawa buku paket, buku latihan dan lainnya.

c) Siswa belum terbiasa mendapatkan model pembelajaran pendekatan keterampilan proses sehingga, terkesan agak kaget menerimanya. Indikatornya adalah saat siswa dipancing untuk menemukan masalah sendiri sangat sulit untuk mendapatkannya sehingga masalah masih diberikan oleh guru, dalam melakukan kegiatan untuk memecahkan masalah juga masih banyak mendapat bimbingan dari guru, sampai kepada menyimpulkan juga masih ditemukan oleh guru.

d) Siswa masih sulit dalam melakukan diskusi kelompok baik diskusi internal kelompok maupun antar kelompok. Sehingga keaktifan siswa dalam bekerja sendiri dan menemukan sendiri masih sangat kurang. Siswa yang mempunyai kemampuan tinggi kurang dapat bekerjasama dengan siswa yang berkemampuan rendah, sedangkan siswa yang berkemampuan rendah enggan bertanya padasiswa yang berkemampuan tinggi. 
Berdasarkan temuan pada siklus 1 ini, Tim peneliti melakukan evaluasi dan refleksi untuk implementasi pada siklus 2 . Hasil evaluasi dan refleksi ini dijelaskan kepada guru agar kekurangan yang terdapat pada siklus 1 dapat diperbaiki atau bahkan dihilangkan. Pada temuan pertama di atas diharapkan guru perlu meningkatkan kemampuannya dalam mengajar dengan pendekatan keterampilan proses. Tim peneliti kembali memodelkan pembelajaran dengan keterampilan proses dan selanjutnya di diskusikan. Hal ini dilakukan agar guru mempunyai keterampilan dan konsep yang tepat dalam mengajar dengan pendekatan keterampilan proses.

Pada temuan kedua diharapkan guru dapat mengimbau dan mengingatkan siswa agar mempelajari materi pelajaran di rumah, serta menyiapkan buku paket atau perlengkapan lainnya sebelum ke sekolah.

Pada temuan ketiga guru diberikan trik trik untuk dapat memancing siswa menemukan permasalahan, dan menemukan sendiri kesimpulan yang diinginkan. Dalam hal ini, guru diingatkan jangan selalu memanjakan siswa, dengan memberikan penjelasan sedetail mungkin sehingga siswa tidak melakukan kegiatan penemuan sendiri.

Pada temuan keempat guru diberikan bekal bagaimana memancing interaksi siswa antar kelompok dan internal kelompok sehingga kegiatan belajar berlangsung dengan lancar sesuai dengan yang direncanakan. Pemberian penghargaan juga dianjurkan dalam hal ini, sebagai motivasi bagi siswa, dan kelompoknya bersaing secara benar.

\section{Siklus II}

Bertolak dari hasil yang diperoleh pada siklus I, maka pelaksanaan pembelajaran pada siklus II diusahakan upaya-upaya perbaikan terhadap cara mengajar guru berdasarkan evalusi dan refleksi dari lembar observasi pembelajaran di kelas. Siklus II dilakukan dengan 8 kali pertemuan dengan pokok bahasan Hukum Newton tentang Gaya. Hasil observasi yang dilakukan pada siklus II ini diperoleh:

a) Dominasi guru dalam mengajar sudah mulai berkurang, tetapi tahapan pokok pembelajaran yang sesuai dengan pendekatan keterampilan proses masih belum dilaksanakan secara optimal karena masih terbawa oleh pola pembelajaran yang lama. Pembatas antara kegiatan awal, inti dan akhir belum kelihatan dan terkesan tidak mempunyai orientasi yang jelas. Indikatornya tujuan dari masing-masing kegiatan pokok tidak tercapai dengan baik. Contoh Pada kegiatan awal seharusnya guru betulbetul dapat memilih kegiatan yang menarik sehingga siswa termotivasi untuk belajar tidak dilakukan dengan baik. Pada kegiatan inti seharusnya tahapan-tahapan keterampilan proses masih dijelaskan oleh guru dan terkesan guru tidak sabar untuk memberikan kesimpulan dan konsep yang benar. Demikian juga pada kegiatan akhir belum kelihatan kaitan antara konsep yangdiajarkan dengan kehidupan seharihari siswa sehingga, pembelajaran dirasakan kurang bermakna.

b) Pada siklus kedua terlihat siswa lebih siap dari sebelumnya karena sudah diingatkan oleh guru pada pertemuan sebelumnya tapi masih ada satu atau dua orang siswa yang belum membawa peralatan belajarnya.

c) Setelah diberikan trik trik untuk memancing siswa sedikit terlihat perkembangannya yaitu kelihatan siswa sudah mulai terpancing untuk menemukan masalah sendiri tetapi sangat sulit untuk mendapatkannya. Dalam proses kegiatan untuk menemukan kesimpulan guru bersama titn peneliti membuat lembar kerja siswa yang berisi keterampilan proses untuk 
menemukan sendiri. LKS yang dibuat masih terlalu detail mengiring siswa sehingga langkahlangkah yang harus dilakukan siswa tergambar jelas. Hal ini, sengaja dilakukan oleh tim untuk menibiasakan siswa dalam melaksanakan keterampilan proses.

d) Dengan pemberian penghargaan kerjasama kelompok sudah mulai terlihat tetapi belum optimal apalagi komunikasi antar kelompok. Siswa kelihatan masih sangat sulit mempresentasikannya dengan baik di depan kelas. Cara presentasi juga harus dibenahi sehingga kelompok yang lain mendapat penyajian hasil kerja yang sederhana dan mullah dimengerti. Dalain hal ini tim mencoba menerapkan model pembelajaran kelompok yang lain tapi tidak terlepas dari strategi pembelajaran keterampilan proses.

\section{Siklus III}

Berdasarkan hasil evaluasi dan refleksi pada siklus II, pelaksanaan pembelajaran pada siklus III dilakukan upaya-upaya perbaikan berdasarkan masukan dari berbagai pihak. Upaya-upaya itu antara lain: a) tim melakukan diskusi dengan guru tentang pembelajaran yang dilakukan pada siklus sebelumnya sehingga diperoleh konsep yang benar tentang pembelajaran keterampilan proses, b) memberikan modeling kepada guru tentang pembelajaran yang dimaksud, c) melakukan real teaching di kelas dengan guru sebagai pengamat dan lain-lain, d) menjelaskan kembali kepada guru tentang strategi pembelajaran yang berorientasi kepada keterampilan proses sehingga guru memiliki keterampilan yang baik dalam mengajar. Siklus III dilakukan 8 kali pertemuan dengan pokok bahasan usaha dan energi, hasil observasi yang dilakukan pada siklus III diperoleh:

a. Dalam mengajar guru sudah melewati tiga tahapan pokok pengajaran tetapi belum terlaksana dengan baik sesuai dengan pendekatan keterampilan proses yang diinginkan. Guru masih mendominasi pembelajaran di dalam kelas dan beds antara tahapan-tahapan pokok pemebalajaran jugs tidak begitu kelihatan. Belum terlihat pembimbingan guru dalam melaksanakan berbagai keterampilan proses seperti menemukan masalah, merumuskan hipotesis, mengamati, dan menarik kesimpulan.

b. Siswa sudah mempersiapkan dengan baik peralatan belajar yang diperlukan hanya mereka belum slap dengan konsep yang ingin diajarkan. Guru diminta memberikan motivasi kepada anak untuk belajar atau mempelajari mater yang akan diberikan guru di kelas.

c. Siswa belum dapat menyimpulkan dan menemukan konsep yang diberikan pada hari itu. Dalam hal ini guru dapat memberikan kahmat-kalimat tanya pengiring atau dilakukan dengan pleno dengan presentasi masing-masing kelompok untuk mencari atau menemukan konsep secara mandiri.

d. Siswa sudah bekerja dengan kelompok, sudah terjadi interaksi dalam internal kelompok dan antar kelompok, tetapi interaksi itu kebanyakan masih merupakan interaksi yang kurang mendukung ditemukannya kesimpulan.

\section{Siklus IV}

Siklus IV hanya dapat dilaksanakan sebanyak 4 kali pertemuan dengan pokok bahasan momentum dan impuls. Dari hasil observasi, evaluasi dan refleksi pada siklus ke empat didapat sebagai berikut:

a. walaupun sudah tampak pembelajaran yang berorientasi pada keterampilan proses tetapi kegiatan pembelajaran masih didominasi oleh guru. Tampaknya hal ini sulit untuk dihilangkan karena sudah menjadi kebiasaan yang cukup 
lama. Olehkarena itu butuh waktu untuk menghilangkannya. Tim dalam hal ini selalu mengingatkan guru yang bersangkutan agar memperhatikannya dimana harapannya intervensi guru dalam pembelajaran harus dikurangi, guru hanya boleh menjelaskan dan berkomentar bila diperlukan saja.

b. Setelah diberikan perlakuan tugas yang hares dikumpulkan pada pertemuan selanjutnya, dimana tugas itu berisi pemahaman hat-hat yang dasar tentang konsep yang akan diajarkan pada pertemuan sekarang maka siswa sudah sedikit mengerti dengan apa yang akan ditemukan.

c. Kesimpulan yang ingin dicapai kadangkadang sudah dapat ditemukan olehsiswa tetapi masih memerlukan bantuan dari guru. Tim berpendapat semua ini adalah proses sehingga membutuhkan waktu untuk dapat terlaksanasesuai dengan kehendak tim.

d. Siswa, sudah mulai terbiasa bekerja secara kelompok tetapi kualitas kerjasamanya masih perlu ditingkatkan olehkarena itu pecan guru masih sangat diperlukan. Kedepan dengan menggunakan strategi pembelajaran kelompok yang sudah ada hat ini dapat diatasi.

Pembelajaran dengan pendekatan keterampilan proses diharapkan dapat mengubah pola pembelajaran lama (konvensional) menjadi pola baru yang berorientasi kepada, siswa, meningkatkan keaktifan dan motivasi siswa dalam belajar dan mendapatkan keterampilan untuk menemukan dan menganalisis sendiri masalah yang dihadapi. Hal in berarti dapat meningkatkan life skill siswa dalam penerapan konsep yang dipelajari dalam kehidupan sehari-hari.

penerapan pembelajaran dengan pendekatan keterampilan proses secara umum dapat meningkatkan kualitas pembelajaran fisika di SMA Negeri 2 Mataram walaupun diakui peningkatan itu belum optimal. Lebih lanjut penerapan pembelajaran ini mampu meningkatkan kemampuan siswa untuk memecahkan masalahnya sendiri dari proses. Guru akan terus memberikan bimbingan demikian pula tim yang lebih intensif kepada siswa yang memiliki tingkat keterampilan awal yang masih rendah, dan mengelola proses bimbingan sedemikian sehingga siswa yang terampil dapat membantu temannya yang belum terampil, sehingga pada akhirnya siswa dapat menemukan masalah sendiri, melakukan kegiatan sendiri, pengamatan sendiri dan pada akhirnya mampu menemukan sendiri (Subrata, 2000). Dalam hal ini guru hanya sebagai facilitator saja dan hanya akan menjelaskan bila diperlukan.

Tabel 1. Data Respon Siswa Kelas XI SMAN 2 Mataram

\begin{tabular}{cccl}
\hline $\begin{array}{c}\text { Jumlah } \\
\text { Responden }\end{array}$ & $\begin{array}{c}\text { Jumlah Skor } \\
\text { Responden }\end{array}$ & $\begin{array}{c}\text { Prosentase } \\
\text { nilai (\%) }\end{array}$ & $\begin{array}{l}\text { Kategori } \\
\text { Respon }\end{array}$ \\
\hline 40 & 3060 & 76,5 & $\begin{array}{l}\text { Sangat } \\
\text { Baik }\end{array}$ \\
\hline
\end{tabular}

$\begin{array}{rrr}\text { Respon } & \begin{array}{r}\text { Siswa } \\ \text { dengan }\end{array} & \begin{array}{r}\text { Terhadap } \\ \text { Pendekatan }\end{array}\end{array}$

Keterampilan Proses Berdasarkan hasil sebaran angket diperoleh data respon siswa terhadap model ini ditunjukkan oleh tabel 1. Berdasarkan tabel 1, jelas terlihat bahwa respon siswa terhadap pembelajaran keterampilan proses sangat baik. Kemudian berdasarkan angket diperoleh:

Tabel 2. Data Angket Siswa Kelas XI SMAN 2 Mataram

\begin{tabular}{lll}
\hline No & \multicolumn{1}{c}{ Pertanyaan } & \multicolumn{1}{c}{ Jawaban Siswa (\%) } \\
\hline 1 & Selama & Senang (95\%) \\
$\cdot$ & mengikuti & Tidak Senang $(0 \%)$ \\
& pelajaran fisika & Biasa biasa saja (5\%) \\
& bagaimana & \\
& perasaanmu & \\
\hline 2 & Seandainya & Banyak praktek/kegiatan \\
$\cdot$ & kamu merasa & $(98 \%)$ \\
& senang hal apa & Guru menyenangkan \\
& saja yang & $(80 \%)$ \\
& menyenangkan & Suasana kelas \\
\hline
\end{tabular}




\begin{tabular}{|c|c|c|}
\hline No & Pertanyaan & Jawaban Siswa (\%) \\
\hline & & $\begin{array}{l}\text { menyenangkan }(85 \%) \\
\text { Banyak hal yang } \\
\text { menyenangkan yang } \\
\text { belum pernah atau } \\
\text { jarang saya alami }(75 \%) \\
\text { Belajar di ruang } \\
\text { Laboratorium }(99 \%)\end{array}$ \\
\hline 3 & $\begin{array}{l}\text { Dibandingka } \\
\text { mata pelajaran } \\
\text { lain yang } \\
\text { pernah kamu } \\
\text { ikuti hal apa } \\
\text { yang paling } \\
\text { berbeda pada } \\
\text { pelajaran ini, } \\
\text { sehingga kamu } \\
\text { senang }\end{array}$ & $\begin{array}{l}\text { Pembelajaran tidak } \\
\text { terlalu serius(70\%) } \\
\text { Menggunakan } \\
\text { peralatan/media }(98 \%) \\
\text { Pendapat siswa sangat } \\
\text { dihargai }(80 \%) \\
\text { Siswa banyak bekerja } \\
(90 \%)\end{array}$ \\
\hline 4 & $\begin{array}{l}\text { Bagaimana } \\
\text { pendapatmu tentang } \\
\text { pembelajaran ini. }\end{array}$ & $\begin{array}{l}\text { Diterapkan pada mata } \\
\text { pelajaran lain }(96 \%) \\
\text { Banyak hal-hal baru } \\
\text { dan menyenangkan } \\
(88 \%) \\
\text { Waktu pelajaran ini } \\
\text { terlalu pendek }(75 \%) \\
\text { Pelajaran ini terasa } \\
\text { semakin mudah }(75 \%) \\
\text { Penjelasan guru jadi } \\
\text { mudah dipahami }(80 \%)\end{array}$ \\
\hline
\end{tabular}

Berdasarkan tabel 2 terlihat jelas pendapat/tanggapan siswa terhadap pembelajaran dengan pendekatan keterampilan proses.

Respon siswa SMA Negeri 2 Mataram terhadap pembelajaran dengan keterampilan proses sangat baik $(76,5 \%)$ dari 40 orang siswa. Hal ini menunjukkan bahwa pembelajaran tersebut mampu membuat siswa senang dengan pembelajaran yang diberikan, karena keterampilan proses adalah satu pendekatan yang berorientasi pada siswa sehingga dapat meningkatkan hasil belajar siswa. Azizirrahim et al. (2015) mengatakan keterampilan proses sains dalam model pembelajaran guided discovery dapat meningkatkan hasil belajar IPA fisika siswa. Tuada et al. (2017) juga menyatakan hal yang sama bahwa keterampilan proses sains adalah faktor penting yang berpengaruh pada perkembangan siswa.

Keterampilan proses sains sangat dibutuhkan oleh siswa. Venisari et al. (2017) dalam penelitiannya menyebutkan bahwa keterampilan proses sains dapat mengembangkan keterampilanketerampilan lainnya, seperti keterampilan pemecahan masalah. Hermansyah et al. (2017) juga menambahkan bahwa pendekatan yang berbasis saintifik dapat meningkatkan kreativitas siswa. Pendekatan proses sains adalah sebuah pendekatan yang melatih berbagai kemampuan yang dibutuhkan oleh siswa, kemampuankemampuan ini sangat berpengaruh pada hasil belajar siswa. Perbaikan pada setiap siklus belajar pada penelitian ini juga menunjukkan bahwa aktivitas siswa terus meningkat dan pada akhirnya kualitas pembelajaran menjadi lebih baik.

\section{PENUTUP}

Dari hasil penelitian yang dilakukan dapat disimpulkan bahwa: Penerapan pembelajaran dengan pendekatan keterampilan proses membuat siswa senang, banyak praktek dan menggunakan alat dan media pembelajaran, hal ini diharapkan dapat meningkatkan kualitas pengajaran fisika di SMA Negeri 2 Mataram. Respon siswa SMA Negeri 2 Mataram terhadap pembelajaran dengan pendekatan keterampilan proses sangat baik dan mereka termotivasi untuk belajar fisika.

Berdasarkan hasil penelitian ini, diharapkan penelitian ini dapat membantu guru di SMA Negeri 2 Mataram atau lainya dalam menerapkan pembelajaran yang sesuai dengan tuntutan kurikulum dan dapat menjadi motivasi untuk mengembangkan pendekatan pendekatan yang lain dalam mengajar.Penelitian ini juga diharapkan mampu menjadi inspirasi bagi peneliti lain untuk berinovasi dalam pembelajaran. 


\section{REFERENSI}

Azizirrahim, E., Sutrio, S., \& Gunawan, G. 2017. Penerapan Pendekatan Keterampilan Proses Sains dalam Model Pembelajaran Guided Discovery untuk Meningkatkan Hasil Belajar IPA Fisika pada Siswa Kelas VIIA SMPN 8 Mataram Tahun Ajaran 2015/2016. Jurnal Pendidikan Fisika dan Teknologi, 1(4), 272-275.

Dahar, W.M. 1989. Teori-Teori Belajar. Jakarta: Erlangga

Hermansyah, H., Gunawan, G., \& Herayanti, L. 2017. Pengaruh penggunaan laboratorium virtual terhadap penguasaan konsep dan kemampuan berpikir kreatif siswa pada materi getaran dan gelombang. Jurnal Pendidikan Fisika dan Teknologi, 1(2), 97-102.

Hikmawati, H., Kusmiyati, K., \& Sutrio, S. (2019). Penerapan Lembar Kerja Eksperimen Untuk Melatih Keterampilan Proses Sains Siswa SMA. Jurnal Pendidikan Fisika dan Teknologi, 5(1), 167-172.

Huda. M. 2013. Model Model Pengajaran dan Pembelajaran Isu-Isu Metodis dan Pragmatis. Yogyakarta. Pustaka Pelajar.

Ibrahim, M. 2000. Pembelajaran Berdasarkan Falsalah. Surabaya: University Press.

Irawan. P. 1997, Teori Belajar. PAU-PPAI. Jakarta. Universitas Terbuka.

Klinger. W. 1997. Survei Metode Pengajaran dalam Ilmu Pengetahuan Alam. Erziehungswiss, Fakultat der Universtat, ErlangenNurnbe

Nur, M. 1988. Keterampilan Proses dan Proses Belajar Mengajar pada Teknologi Kejuruan. Laporan Penelitian. IKIP Surabaya.

Ramdhani, A. 2005. Optimalisasi Pembelajaran Fisika Dengan
Penggunaan Kit IPA di SMP N 6 Mataram, Unram Press, Mataram

Santyasa, 1997. Pembelajaran Modul dengan Metode Demontrasi dah Analogi Sebagai Strategi Pengubah Miskonsepsi Mahasiswa Jurusan Pendidikan MIPA. Laporan Penelitian. STKIP Singaraja.

Subrata, 2000. Upaya Peningkatan Kualitas Hasil Belajar Siswa SD melalui Pembelajaran IPA dengan Keterampilan Proses. Laporan Penelitian. STKIP Singaraja.

Suwandari, P. K., Taufik, M., \& Rahayu, S. 2018. Pengaruh Model Pembelajaran Inkuiri Terbimbing Terhadap Penguasaan Konsep dan Keterampilan Proses Sains Fisika Peserta Didik Kelas XI MAN 2 Mataram Tahun Pelajaran 2017/2018. Jurnal Pendidikan Fisika dan Teknologi, 4(1), 82-89.

Tuada, R. N., Gunawan, G., \& Susilawati, S. 2017. Pengaruh Model Pembelajaran Generatif Dengan Teknik Guided Teaching Terhadap Keterampilan Proses Sains. Jurnal Pendidikan Fisika dan Teknologi, 3(2), 128-136.

Venisari, R., Gunawan, G., \& Sutrio, S. 2017. Penerapan Metode Mind Mapping pada Model Direct Instruction untuk Meningkatkan Kemampuan Pemecahan Masalah Fisika Siswa SMPN 16 Mataram. Jurnal Pendidikan Fisika dan Teknologi, 1(3), 193-199. 